\title{
FACTORS AFFECTING THE VOLUME OF TRADE ON SEAFOODS IN UMUAHIA MARKETS, ABIA STATE, NIGERIA
}

\author{
R.O Mejeha, I.O Obasi and A.U Ezeasor \\ Department of Agric Economics, Michael Okpara University of Agriculture, Umudike
}

\begin{abstract}
The broad objective of this study is to examine the factors affecting the quantity of sea foods traded in Umuahia markets in Abia State, Nigeria. Two sets of structured questionnaire were used to collect data from iced fish traders, (wholesaler and retailers) and periwinkle retail traders. A total of 100 traders of sea foods randomly selected from four markets were interviewed. They consist of 30 wholesalers and 40 retailers of iced fish, and 30 retailers of periwinkle. Simple statistical tools such as percentages, frequency distribution and the regression analysis were applied to the data collected. Results show that the commodities were supplied from distant places, namely; Rivers, Bayelsa, Akwa Ibom, Delta and Cross River States. Factors that have significant effect on the quantity of wholesale trade on iced fish are household size, level of education, operating capital and the commodity price. Income from secondary occupation is significant in affecting retail trade on the iced fish while years of trading experience was statistically significant in affecting retail trade on periwinkle. The F-ratios were significant. The $R^{2}$ showed that the variations in the dependent variable were captured by the independent variables. Formulation of policies that will encourage inter-State is recommended.
\end{abstract}

Key words: Seafoods, Trade, Markets, Abia State

\section{INTRODUCTION}

Seafood is any marine estuarine or fresh water fish or other aquatic organism intended for human consumption which does not include crocodile or aquatic plant (Roberts \& Huner, 1993). About $72 \%$ of harvested fish and shellfish worldwide are used for human consumption (Robert and Hunner, 1993). Seafood contributes about $90 \%$ of the protein consumed worldwide. Sea-foods are an important source of protein for the majority of people in Abia State, Nigeria. Given this fact, trade in the commodities especially iced fish and periwinkle enable consumers to have access to the goods. In recent years, there has been a growing demand for seafoods, which has led to increase in production.

It is estimated that between 1985 and 1989, world consumption of all seafood species increased by $15 \%$ (periwinkle and shellfish increased at a rate of $22 \%$, finfish at a rate of $14 \%$ ). This increase in consumption has sensitized production resulting in improvement in the agricultural sector. Sea food production is very important in Nigeria because, the sub sector contributes substantially to the Gross Domestic Product (GDP) of Nigeria (NBS, 2006).

International Labour Organization (I.L.O). (1999) noted that traditional seafood distribution channel typically involves two or three stages from fishermen, to processor, to various retail outlets or brokers. This fact brings to light the importance of marketing in the economy. The role of marketing is more crucial in areas where there are high level of commercial activities and high 
rate of urbanization (Olokosi \& Isitor, 1990). The marketing process serves as an incentive to seafood production and productivity (Odii \& Ibih, 2000).

The segment of the population mostly affected by the problem of food insecurity is the poor and urban dwellers. Urban locations are legally or administratively defined on the basis of threshold population particularly in terms of population size and density, heterogeneity, structure and economic base. High population size (20,000 or more inhabitants), with attendant pressure on environmental resources, public utilities, schools, markets and hospitals, is indicator of urbanization (NBS, 2006).Majority of urban dwellers do not produce their own food. Consequently, they depend on food produced in the rural areas (Okereke, 1993). The best means of guaranteeing food security for the urban population is, therefore, to encourage the process that would facilitate the flow of food from producing areas to the cities (Adegeye \& Ditto, 1985). Marketing process creates time, place and form utilities. Another point that underscores the importance of marketing is that some local markets are not able to absorb surplus agricultural produce (Idachaba, 1980). The problem, therefore, is that while there are surpluses in producing areas, some urban residents suffer from hunger and malnutrition.

The effect of the marketing process is assessed by the ability of the market to create time, place, form and possession utilities. Efficient marketing process is that which is capable of providing sufficient food to the populace through the process of market mechanism (Mejeha et. al., 2000). In fact, an efficient marketing system is that which locates where there are surplus of produce and brings them to where there are shortages (Kohls \& Uhl, 1980). The marketing process aids the movement of commodities from the farmers to the consumers and these include assemblage of products, storage, transportation, grading and financing of all these activities, (Kohl \& Uhl, 1980). The movement of commodities from the producer to the final consumer passes through different categories of intermediaries or marketing channel. Marketing channel refers to the sequence of intermediaries through which goods move from the producers to consumers (Kohl \& Uhl, 1980). Channels of distribution are concerned with the process of bringing a commodity from producers to the users. Channels can be centralized or decentralized (Butterworth, 1982, Adekanye, 1993).

Marketing of agriculture produce in Nigeria faces many problems. Idachaba, (1980) noted that the problem of feeding the non farm urban population was not the instability of food production but the instability of marketable surplus which is affected by losses in the distributive system. Related to these are lack of proper post-harvest handling and processing facilities as well as infrastructural inadequacies. Okereke (1993) observed that the marketing problems in Nigeria are that both physical and institutional.

The major problems facing the marketing of agricultural commodities include transportation, communication, storage, handling, packaging and processing, marketing intelligence, credit and prices (Gyanendra, 1993). Seafood being perishable in nature requires fast delivery, proper handling storage and distribution, which can be achieved through improved infrastructural and institutional facilities. These marketing problems have to a great extent produced adverse effects 
on the quantity and quality of food items sold in Umuahia markets. These problems over time have led to the existence of food supply gap and food insecurity in the study area (Mejeha et. al., 2000). The broad objective of this study is to examine factors that affect the quantity of seafoods traded in Umuahia markets. The specific objectives are to; ascertain the sources of supply of the seafoods; iced fish and periwinkle, identify factors affecting the volume of the commodities traded and identify constraints associated with the marketing of the commodities.

\section{Materials and Method}

The study was conducted in Umuahia North and Umuahia South Local Government Areas (L.G.A.s) of Abia State, Nigeria. In the study area, there are 10 communities and each of which has at least one major or feeder market. Major markets in the area include among others, Ogwumabiri Umuahia, Timber shade market, Afor Ibeji, Apumiri, Nkwoegwu, Orie Ugba na Nkata, Ahiaukwu Olokoro, Orieamaenyi and Nkwoha. For this study, iced fish and periwinkle were selected. The choice of the commodities is because they are widely accepted by people and the commodities are rich in protein and are capable of competing favourably with meat from animal source. For the purpose of data collection, two major markets were purposively selected from each of the L.G.As. The two markets are Ogwumabiri Umuahia and Timber Shade markets for Umuahia North and Afor Ibeji and Nkwoha for Umuahia South. The basis for the selection of the markets is because the bulk of the commodities studied, (iced fish and periwinkles) are handled in abundant quantities in these markets.

Our sample was drawn from iced fish and periwinkles traders. The random sampling procedure was used in the selection of respondents. Thirty wholesalers and 40 retailers of iced fish and 30 retailers of periwinkle were selectd giving a total of 100 respondents. Seven wholesalers per market for Timber market, Afor Ibeji market and Nkwoha market; 9 wholesalers were sampled from the larger Ogwumabiri Umuahia Market making a total of 30 wholesalers .The same sampling frame was used for retailers of periwinkle giving a total of 30 retailers. There is no wholesaler of periwinkle in the markets. For the retailers of iced fish, 10 respondents were sampled from each of the 4 markets making a total of 40 iced fish retailers. Data collected were analyzed with the use of charts and figures which show the channels of distribution of iced fish and periwinkle into Umuahia markets. Furthermore, simple statistical tools such as percentages and frequency distribution tables were applied to the data. Regression analysis was used to examine variables that exert some influence on the quantity of the commodities handled by the traders.

The implicit functional form for the regression model is:

Qt $=\mathrm{f}(\mathrm{x} 1, \mathrm{x} 2, \mathrm{x} 3, \mathrm{x} 4, \mathrm{x} 5, \mathrm{x} 6, \mathrm{x} 7, \mathrm{x} 8, \mathrm{e})$ Where;

$\mathrm{Q}_{\mathrm{t}} \quad=\quad$ Quantity of the commodity traded by the trader $(\mathrm{kg})$

$\mathrm{X}_{1}=$ Sex (one (1) for male, zero (0) for female)

$\mathrm{X}_{2}=$ Age of the respondents (years).

$\mathrm{X}_{3}=$ Household size, the number of people who are living with the respondent

$\mathrm{X}_{4}=$ Marital status, $($ married $=1$, single $=0)$. 


$\mathrm{X}_{5}=\quad \begin{aligned} & \text { Educational level, number of years the respondent spent in School } \\ & (\mathrm{yrs})\end{aligned}$
$\mathrm{X}_{6}=\quad \begin{aligned} & \text { Trading experience, measured as the number of years the } \\ & \text { respondents have been in the business }(\mathrm{yrs}) .\end{aligned}$
$\mathrm{X}_{7}=\quad \begin{aligned} & \text { Income from non trading sources, (gifts and income earned } \\ & \text { from the source) }\end{aligned}$
$\mathrm{x}_{8}=\quad \begin{aligned} & \text { Trading capital }- \text { monetary investment made in running the } \\ & \text { business }(\#)\end{aligned}$
$\left.\mathrm{X}_{9}=\quad \begin{array}{l}\text { Commodity price }- \text { the prevailing price of the commodity } \\ \text { within the period }(\end{array}\right)$
ei $\quad \begin{aligned} & \text { The error term. }\end{aligned}$

The apriori expectations are stated as follows: Age, trading experience, trading capital and educational attainment are expected to relate positively with the quantity of the commodity handled. This implies that, as the variables increase in magnitude, the quantity of the commodity traded by the respondent increases. On the other hand, household size of the respondent and the purchase price of the commodity are theoretically expected to have negative relationship with the quantity of the commodity handled by the respondents. This suggests that as the variables increase, the quantity of the commodities traded decrease.

\section{Results and Discussion}

In this section, we discuss marketing related variables which could exert some influences, positive or negative, on the quantity of sea foods traded in Umuahia markets. These include the sources of supply of the commodities, the categories of middlemen involved in the marketing channel, the socioeconomic characteristics of the traders and problems associated with the marketing of the commodities.

\section{Sources of the supply of commodities to Umuahia Markets}

The major source of supply of the commodities are the Niger Delta region of Nigeria and some foreign countries including the Cameroun and Norway where there are large bodies of waters and advanced technology of production. Major areas of supply within Nigeria include Rivers, Bayelsa, Akwa Ibom, Delta and Cross Rivers States.

Given the fact that the commodities are supplied from outside Abia State, this has some economic implications in relation to their availability and to the quantities traded. First, the distant places from which the commodities are supplied affect the cost of transportation, which increases the marketing cost. Secondly, given the fact that the commodities are perishable goods, the traders need facilities for preservation for the period the marketing activities last. Third, the supply of the commodities could be sustained only when transportation and storage facilities are available and affordable by the traders. This means that any interruption in the transportation system, will automatically lead to disruption in the supply of the commodities. 


\section{Marketing channel for iced fish in Umuahia}

Figure 1 shows the marketing channel for iced fish. It shows alternative routes through which the commodity passes starting from the producer (the fish farmer) to the final consumers.

Figure 1 suggests that, on its route to the final consumer in Umuahia, the commodity passes through some market intermediaries known as middlemen. At least five categories of middlemen are involved in the marketing channel. They include importers, marketing firms, wholesalers,

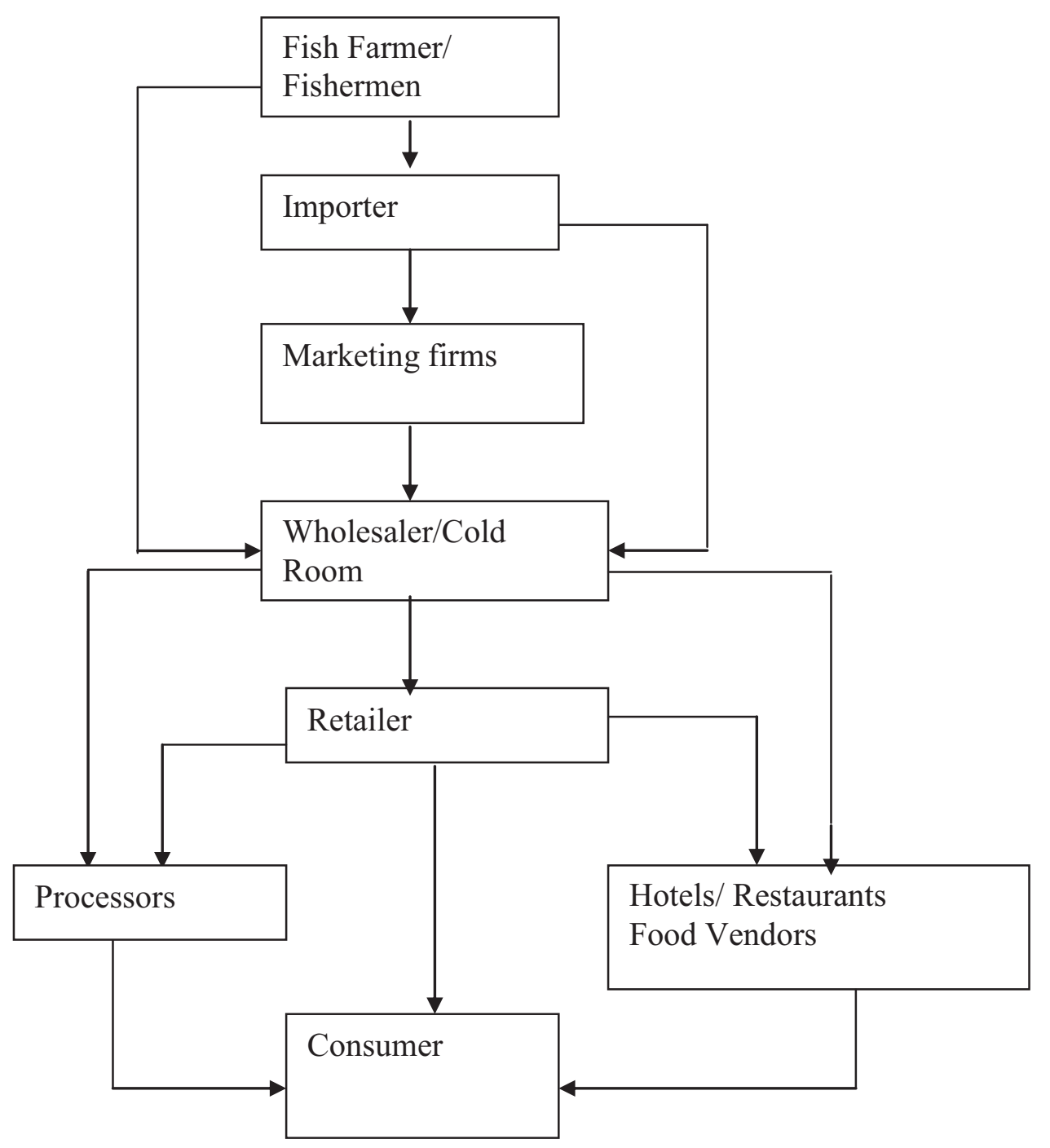

retailers and sometimes processors. Each of these channels performs important marketing functions. The functional designation of middlemen determines the quantity of the commodity traded. For instance, the importer handles bigger quantity of the commodity than the wholesaler, while the wholesaler handles more volume of the commodity than the retailer. Retailers most often, process iced fish (by drying) as a means of preservation. The control of iced fish 
marketing in Umuahia markets is essentially in the hands of wholesalers who have a great influence on the price and the quantity of the commodity that could be supplied to the markets. This is so because of distance; neither the retailer nor the consumer has direct contact with the major supplies (the importers), and the marketing firms. This type of market situation makes it possible for wholesalers to have a collusive agreement which usually entails the assignment of market quotas to trading partners. With such agreement in place, the quantity of iced fish traded will be predetermined but not controlled by market forces. The channel of distribution for iced fish differs from those of staple foods like garri, and yam as noted by Anuebunwa (2002) and Echebiri and Mejeha, (2004). For those commodities, the channel of distribution is simpler.

Figure 2, suggests that the marketing channel for periwinkle is a simple one. It involves essentially, three categories of middlemen, namely, the producer, the wholesaler and the retailer. In consideration of the fact that producers are very far from the consumers, the functions of the middlemen in making the commodity available to the consumer is very important. Figure 2 shows the marketing channel for periwinkle in Umuahia.

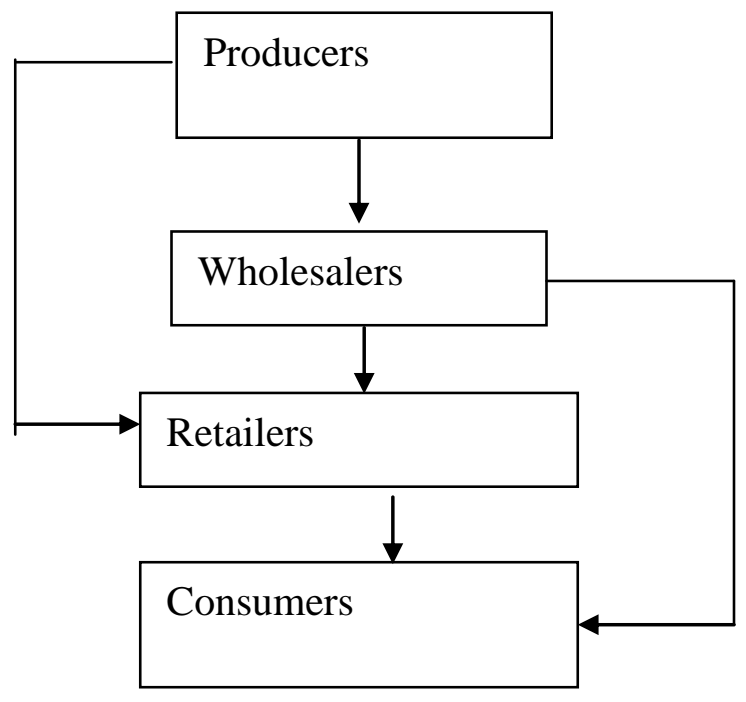

Figure 2 Marketing Channel forPperiwinkle.

\section{Factors affecting Seafood Trade in Umuahia}

The regression results in Table I show the effect of some socio-economic factors on seafood trade in Umuahia markets. The functional forms chosen as the lead equations are the double -log for wholesalers, and retail trade on iced fish, and the semi-log for retail trade on periwinkle based on value of the $\mathrm{R}^{2}$, significance of the F-ratio, number of significant variables and conformity with apriori expectation. In all the equations, the values of the coefficient of multiple determinations $\left(\mathrm{R}^{2}\right)$ were statistically significant and fairly high. For wholesale and retail trade on iced fish, the $\mathrm{R}^{2}$ values were 0.806 and 0.683 respectively. It was 0.813 or 81.30 percent for 
periwinkle trade. Furthermore, results obtained from most of the explanatory variables in the model agree with theoretical and economic expectations.

Table 1 shows that five (5) variables are statistically significant in affecting wholesale trade on iced fish in Umuahia markets. The variables are age of the trader, household size, level of education, operating capital, and the commodity's purchase price. Age, has a significant positive effect on the quantity of the commodity traded. The implication is that older traders handle more quantities of the commodity than traders who are relatively young. This result appears to be consistent with theoretical expectations because, over time, the older traders had got many acquaintances and goodwill which could have given them business advantage. Household size has a significant negative effect on the quantity of iced fish traded by wholesalers. The result suggests that, traders whose household are made up of more people trade less quantity of the commodity than those whose household members are few. Intuitively, respondents with larger household members are expected to spend more of their income on family consumption and less of it on investment and other uses.

The influence of level of formal education is negative on the quantity of wholesale trade on iced fish. This result appears to be contrary to theoretical expectation. This situation could be attributed to the fact that marketing activities involving iced fish trading do not require much of formal education or academic exercise. Trading skills required for the business are acquired through routine activities and practices.

The quantity of wholesale trade in iced fish is positively affected by the operating capital. The variable is statistically significant at one percent. The implication of the result is that traders who have more operating capital trade more iced fish than those with less capital. The result agrees with apriori expectations because, the amount of capital investments determines the volume of business activities.

The purchase price has a significant indirect effect on the quantity of wholesale trade on the commodity. This result is consistent with theoretical expectation especially in relation to the theory of demand. Specifically, this result agrees with the popular law of demand, which expresses the relationship between the changes in commodity price and the quantity demanded at a given period of time.

The variables which are statistically significant in affecting the quantity of retail trade in iced fish include, sex, age of traders, level of formal education, and secondary occupation. 
Table 1: Regression Results on Factors Affecting Seafoods Trade in Umuahia

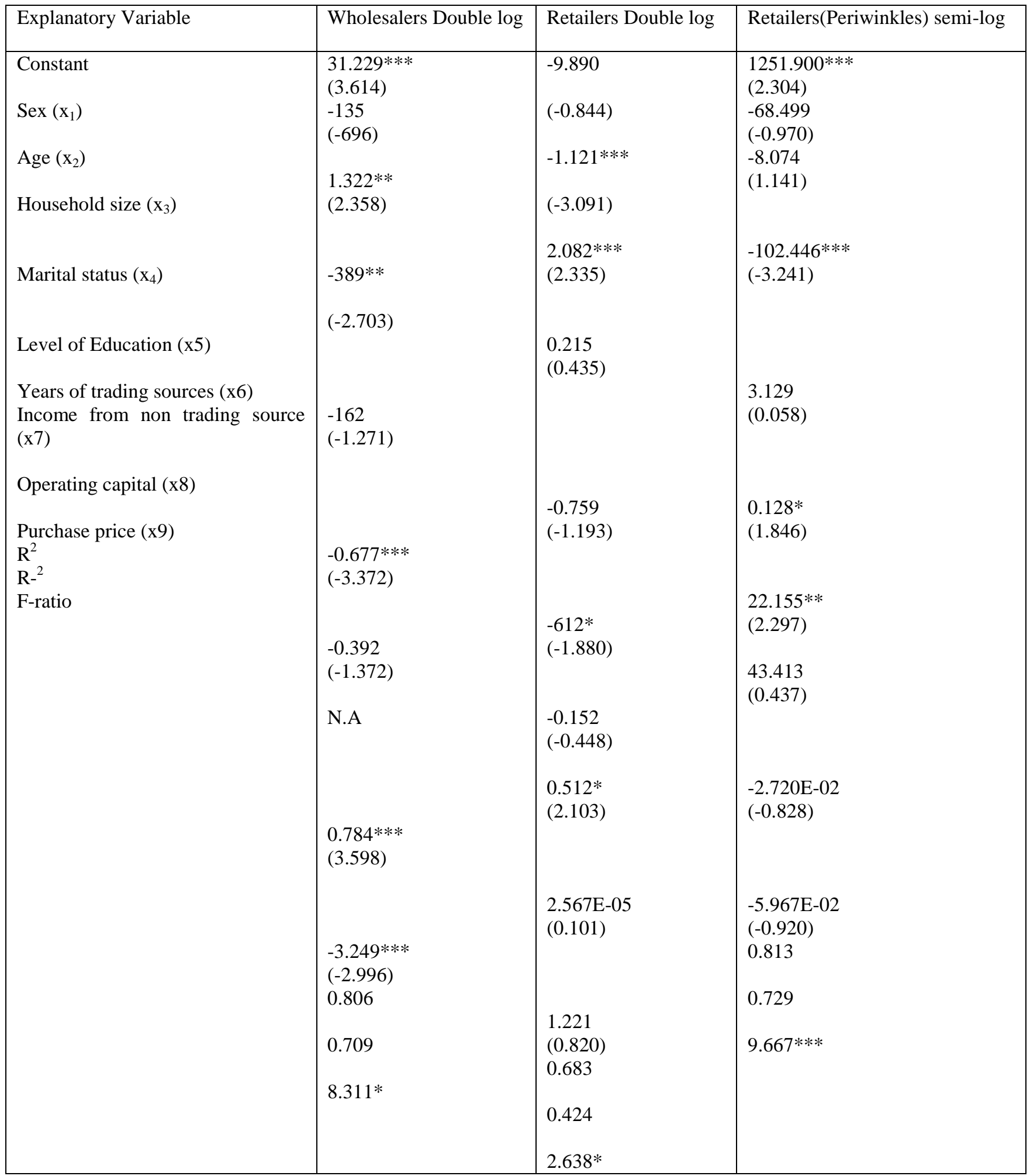

Source: computations from field data, 2006

$* * *$ - significant at $1 \%, * *=$ Significant at $5 \%, *$ at $=$ Significant at $10 \%$.Values in parenthesis are standard errors of bs. NA = Not applicable. 
Age of the respondent have positive and significant effect on the quantity of retail trade in iced fish. The result suggests that older traders sell larger quantities of the commodity than younger traders. This finding could be explained given the fact that older traders have gained more experience and more business acquaintances which might have them competitive advantage over their younger business colleagues.

The effect of the level of formal education on the quantity of iced fish traded at the retail level was negative and significant. The result appears to be in disagreement with theoretical expectation. The finding could imply that majority of the traders spent few years in acquiring formal education.

Sex of the respondent had a negative and significant effect on the quantity of the commodity. The result suggests that, the participation of more women in the retail trade of iced fish leads to increase in the quantity of the commodity handled; conversely, when more men are involved in the retail trade, less quantities of the commodity will be traded. The implication of this finding is that women play important role in the retail trade of iced fish in Umuahia markets.

Income from secondary occupation has a positive and significant effect on the quantity of retail trade in iced fish. This finding agrees with theoretical expectations. The reason is because, income plays important role in capital accumulation and investment.

For retail trade in periwinkle, the household size, level of formal education and years of trading experience had significant effect on the quantity of periwinkle trade. Years of experience on trading have a significant positive effect on the quantity of periwinkle retailed in the area. The result is in agreement with theoretical expectation because of the fact that, experience affords the traders opportunity to master the skill required to handle the commodity. This variable is very important because, periwinkle being a perishable commodity requires expertise and skill.

The influence of household size on the quantity of periwinkle traded was negative and significant. The result suggests that respondents whose households were larger in number handled less quantities of periwinkle. This finding could be explained by the fact that households which are made up of more people spend more of their income for the upkeep of their family members with less of the income left for investment.

Level of formal education has positive relationship with the quantity of periwinkle traded. This result suggests that the traders who acquired more formal education traded more quantities of periwinkle. This finding agrees with theoretical expectations because, formal education helps people to acquire better managerial ability than those who have no formal education. 


\section{Problems of Marketing Sea Foods}

In Table 2 the common problems affecting trade on sea food are presented. In this section we discussed the wholesale and retail trade in iced fish and the retail trade in periwinkle. Periwinkle is mainly marketed at retail level.

\section{Table 2: Common Market}

Table 2 shows the most common problems affecting wholesale trade in iced fish are handling risks, irregular electricity supply and high cost of marketing. The traders encounter handling risks from two main sources: low demand for the commodity and irregular power outage. Marketing costs consist of those associated with transportation, handling, storage, rents, bills and wages. Major marketing problems encountered by traders who retail iced fish are high spoilage, shortage of storage facilities and handling risks from two main sources, namely low demand for the commodity and irregular power outage. Marketing costs consist of those associated with transportation, handling, storage, rents, bills and wages. Major marketing problems encountered by traders who retail iced fish are high spoilage, shortage of storage facilities and handling risk. For retail trade in periwinkle, the major common problems are handling risk and high spoilage due to limited access to storage facilities. These problems are common in some less developed countries (Lele 1971; Parmod \& Sharma, 2003). Implication of the result is that since the control of these problems are beyond the traders, their effect may likely impact negatively on the quantity of the commodities traded in Umuahia.

\section{Conclusion and Recommendations}

Seafood marketing in Umuahia is important because many participants are involved. In view of the fact that the two commodities are supplied from places far from the study area, the participation of many middlemen is necessary. Marketing costs was identified as one of the major marketing problems. The perishable nature of the two commodities pre-disposes the goods to high risk and this particular problem limited the quantity handled by the risk averse traders. For the quantity of the marketed commodities to be increased, there should be marketing related incentives that could reduce such marketing problems as irregular supply of light, handling risks and transportation. The absence of such incentives could render the trade on sea foods in the area unstable.

Based on these findings the following recommendations are made. In view of the fact that the commodities are supplied from distant places, the Federal Government of Nigeria should improve transportation facilities; such improvement should be capable of reducing the marketing cost. In order to increase the volume of sea foods traded in the area, those socio-economic variables that have positive effect on the quantity of the commodity should be reinforced. The supply of electricity in a more regular basis is very important in order to maintain regular supply of the commodity. Federal and State governments should provide the enabling environment for the smooth operation of inter-state trade on sea foods. These when achieved will go a long way in encouraging increase in the volume of the commodities traded in Abia State, Nigeria. 


\section{References}

Abbott, J.C. and Markeham, J.P. (1986). Agricultural Economics and Marketing in the Tropics, Longman Group Ltd. London.

Adegeye, A.J. and Dittoh, J.S. (1985). Essential of Agricultural Economic, Center of Agricultural and Rural Development (CARD) University of Ibandan.

Adekanye, T.O. (1993). Reading in Agricultural Marketing, Department of Agricultural Economics. University of Ibandan. Mexico Enterprises Ltd. Lagos.

Anuebunwa, F.O.(2002). A Structural Analysis of Yam Trade flows into Abia State of Nigeria. The Nigerian Agricultural Journal, Vol. 33 (2002).

Butterworth, S. (1982). Advanced Management Accounting. Third Edition. Prentice Hall, USA.

Crammer, G.L. and Jenson, C.W. (1991). Agricultural Economics and Agricultural Business, New York ,Joan Wiley and Sons, IAC.

Echebiri, R.N. and R.O. Mejaha, (2004). An Analysis of the Conduct and Efficiency of Garri Market in Umuahia area of Abia State, Nigeria. Journal of the Science of Agricultural, Food Technology and the Environment Vol.4

Gyanendra, S. (1993). Product, Processing, Utilization and Marketing of food legumes and grains in Indian. Proceeding of a workshop in Serdang, Malaysia, May $24-$ 27,1993

Idachaba, F.S. (1980) "Food policy in Nigeria: Towards a framework of Analysis" Agricultural Research Bulletin Vol. 1, No. 1 Faculty of Agriculture and Forestry,University of Ibadan, Nigeria.

International Labour Organization (1999). Safety and Health Industry, Geneva, ILO.

Kohls, R.E. and Uhl, J.N. (1980). Marketing Agricultural products, Macmillan Publishing Company, New York..

Lele, U.J (1971) Food grain marketing in Indonesia, privet performance and public policies: Ithaca New York, Cornel University Press.

Mejehe, R.O., Ifenkwe, G.E., Nwosu, A.C. (2000). Analysis of marketers for urban. Monograph submitted to Michael Okpara University of Agriculture, Umudike, 2002. 
National Bureau of Statistics (2006). Annual abstract of Statistics 2006, 406-406.

Odii, M.C.A. and Ibih, O. (2000). Modern form Management Technique, Alphabet Nigeria Publisher, Owerri.

Okereke, O. (1993). The socio-economic impact of Grri Traders Association in Imo State, Oxford Agrarian Studies, Vol. xiv, pp. 92-103.

Olukosi, J.O. and Isitor, S.U. (1990). Introduction to Agricultural Marketing and Prices. Principles and Application G.U Publication Abuja.

Parmod K and Sharma R.K (2003) Spatial price integration and pricing efficiency. A study of paddy in Haryana, India Journal of Agric Economic, pp 201 - 217

Robert, M.W, Huner, J.U. (1993) Phylogeny of commercially important sea food and description of sea food industry. Chin Rev. Allergy, 11. 159-181.

Scarborough, V. and Kydd, J. (1992). Economic Analysis of Agricultural Markets; A manual, Chatham, U.K., Vol.5. 